\title{
PENGARUH KUALITAS PELAYANAN DAN FASILITAS TERHADAP KEPUASAN KONSUMEN KERETA API COMMUTER LINE (STUDI KASUS COMMUTER LINE ARAH CIKARANG KE JAKARTA KOTA)
}

\author{
Popon Rabia Adawia ${ }^{1}$, Ayu Azizah ${ }^{2)}$, Yenia Endriastuty ${ }^{3)}$, dan Sugandi ${ }^{4)}$ \\ ${ }^{1}$ Program Studi Sistem Informasi, Fakultas Teknik dan Informatika, Universitas Bina Sarana Informatika \\ ${ }^{2}$ Program Studi Akuntansi, Fakultas Ekonomi dan Bisnis, Universitas Bina Sarana Informatika \\ ${ }^{3}$ Program Studi Manajemen, Fakultas Ekonomi, STIE Dharma Agung \\ ${ }^{4}$ Program Studi Administrasi Bisnis, Fakultas Ilmu Administrasi Bisnis, Institut STIAMI \\ 1,2 Jl. Kramat Raya No. 98, Senen Jakarta Pusat, 10450 \\ 3 Jl. Industri No. 33 Cikarang Utara, Bekasi Jawa Barat \\ ${ }^{4}$ Jl. Industri Raya No. 69 Cikarang, Bekasi Jawa Barat \\ E-mail : popon.pra@bsi.ac.id ${ }^{1)}$, ayu.azz@bsi.ac.id ${ }^{2}$, yeniadharmaagung@gmail.com ${ }^{3)}$, Soegandi.95@gmail.com ${ }^{4}$
}

\begin{abstract}
ABSTRAK
Kereta api commuter line sebagai salah satu alat transportasi di darat dengan multi keunggulan, sehingga sangat diminati oleh para pengguna transportasi darat untuk menunjang berbagai aktivitas. Sebagai penyedia tunggal jasa transportasi kereta api commuter line di Jabodetabek, PT KCI (Kereta Commuter Indonesia) diharapkan dapat melakukan peningkatan kualitas dan fasilitas pelayanan terhadap peningkatan kepuasan para pengguna jasanya. Penelitian ini bertujuan untuk menganalisis pengaruh kualitas pelayanan dan fasilitas terhadap kepuasan konsumen di rute Cikarang - Jakarta Kota khususnya di stasiun Cikarang, Cibitung, Tambun, dan Bekasi Timur. Metode penelitian ini adalah menggunakan metode kuantitatif. Penganalisan data menggunakan software pengolahan data statistik yaitu SPSS. Populasi penelitian ini adalah pengguna jasa moda transportasi masal kereta api commuter line rute Cikarang - Jakarta Kota. Sampel dalam penelitian ini terdiri dari 100 responden. Metode kuantitatif dengan mengambil data primer menggunakan metode kuesioner dan wawancara. Hasil penelitian menunjukkan variabel kualitas pelayanan berpengaruh signifikan terhadap kepuasan konsumen. Semakin baik kualitas pelayanan yang diberikan maka semakin tinggi kepuasan konsumen terhadap PT KCI. Untuk variabel fasilitas berpengaruh signifikan terhadap kepuasan konsumen, sehingga apabila fasilitas yang diberikan semakin baik maka kepuasan konsumen juga semakin tinggi terhadap PT KCI. Berdasarkan hasil penelitian, kualitas pelayanan dan fasilitas mempengaruhi secara positif dan signifikan terhadap kepuasan konsumen PT KCI baik dalam perhitungan dengan parsial maupun bersama-sama (simultan).
\end{abstract}

Kata Kunci: Commuter Line, Fasilitas, Kepuasan Konsumen, Kualitas Pelayanan

\section{PENDAhuluan}

Saat ini perkembangan dari berbagai sektor ekonomi berkembang dengan sangat cepat. Baik dalam sektor barang maupun jasa menunjukkan peningkatan yang cukup signifikan. Dengan peningkatan kegiatan yang cukup tinggi ini, tentunya masyarakat dituntut memiliki mobilitas yang tinggi. Dengan mobilitas yang tinggi ini masyarakat tentunya membutuhkan suatu saran transportasi yang efektif agar dapat menunjang segala aktivitasnya.

Pada saat ini pusat kegiatan perekonomian Indonesia masih berpusat di Jakarta. Hal ini tentunya melibatkan banyak individu yang bukan hanya berdomisili di Jakarta saja tapi dari berbagai daerah di sekitarnya untuk dapat beraktivitas di kota ini. Kebutuhan akan jasa transportasi yang dapat menunjang aktivitas para pekerja dari luar daerah Jakarta menjadi hal sangat dibutuhkan. Salah satu sektor jasa yang vital bagi masyarakat yaitu sektor jasa transportasi. Hal ini dikarenakan transportasi khususnya transportasi umum menjadi salah satu kebutuhan pokok masyarakat terutama untuk masyarakat perkotaan (Ardi, F.F, Mariam, I dan Widhi, 2016). Terdapat beberapa alternatif yang dapat digunakan, diantaranya yang paling diminati saat ini adalah transportasi dengan menggunakan kereta api commuter line.

PT Kereta Api Commuter Indonesia (PT KCI) adalah anak perusahaan dari PT Kereta Api Indonesia (Persero). PT Kereta Api Commuter Indonesia (PT KCI) merupakan penyelenggara jasa angkutan kereta api di daerah Jabodetabek. Dibentuknya anak perusahaan ini, dimaksudkan agar perusahaan dapat lebih fokus dalam melayani kebutuhan transportasi masyarakat yang tinggal di kota sekitar Jakarta untuk mobilitas di dalam kota Jakarta melalui jasa kereta api Commuter Line Jabodetabek.

Jenis transportasi kereta api commuter line sangat populer dan digemari oleh masyarakat karena memiliki keunggulan lebih dari jenis transportasi lainnya. Commuter line dinilai mode transportasi yang paling ekonomis bagi masyarakat, tentunya hal ini yang 
menjadi pertimbangan mengapa commuter line ini menjadi primadona bagi para pekerja lintas daerah yang bekerja di Jakarta, selain itu waktu keberangkatan dan kedatangan lebih akurat sehingga dapat meminimalisir keterlambatan ketika sampai di tempat bekerja. Dari beberapa keunggulan yang diberikan oleh kereta api commuter line terdapat beberapa hal yang sebaiknya dapat diperbaiki oleh pihak pengelola saat ini. Hal yang berkaitan dengan kualitas pelayanan dan fasilitas yang disediakan oleh pihak pengelola sangat diharapkan dapat lebih ditingkatkan agar sesuai dengan yang diharapkan oleh para pengguna moda transportasi tersebut sehingga kepuasan para pengguna dapat meningkat.

Semua lini dalam perusahaan kereta api commuter line ini diharapkan dapat berfokus pada peningkatan kepuasan para pengguna layanan. Menurut (Lovelock, 2011) Kepuasan adalah suatu sikap yang diputuskan berdasarkan pengalaman yang didapatkan. Kepuasan merupakan penilaian mengenai ciri atau keistimewaan produk atau jasa, atau produk itu sendiri, yang menyediakan tingkat kesenangan konsumen berkaitan dengan pemenuhan kebutuhan konsumsi konsumen. Kepuasan konsumen dapat diciptakan melalui kualitas, pelayanan dan nilai. Kunci untuk menghasilkan kesetiaan pelanggan adalah memberikan nilai pelanggan yang tinggi. Seluruh lini di dalam perusahaan terutama adalah para front liner diharapkan dapat memberikan pelayanan yang optimal kepada para konsumen, front liner yang ramah dan informatif tentunya dapat menciptakan kepercayaan serta perasaan nyaman kepada para penumpang. Keinginan konsumen merupakan hal yang sangat penting untuk diketahui oleh perusahaan. Apabila perusahaan mengetahui apa yang diinginkan oleh konsumennya maka perusahaan dapat berfokus pada hal yang dianggap penting tersebut serta berupaya meningkatkan kinerja sehingga dapat memberikan kepuasan yang optimal bagi para konsumen.

Dalam kenyataannya keluhan pelanggan commuter line terkait dengan kepuasan pelayanan selalu ada. Hal ini tidak dapat dipungkiri. Apalagi jadwal keberangkatan kereta di jam-jam sibuk yang selalu penuh dan padat menjadi keluhan tersendiri bagi para pelanggan. Ketidakpuasaan pelanggan mengenai hal ini dapat di atas oleh pihak PT KCI salah satunya dengan menambahkan armada commuter line khususnya di jam-jam sibuk

Untuk meminimalisir tingkat keluhan para pelanggan perlu juga ditingkatkan kualitas pelayanan. Menurut (Hardiansyah, 2011), menyatakan bahwa kualitas pelayanan adalah sesuatu yang berhubungan dengan terpenuhinya harapan/kebutuhan pelanggan, dimana pelayanan dikatakan berkualitas apabila dapat menyediakan produk dan jasa (pelayanan) sesuai dengan kebutuhan dan harapan pelanggan. Dalam hal ini, kualitas pada dasarnya terkait dengan pelayanan yang baik, yaitu sikap atau cara karyawan dalam melayani pelanggan atau masyarakat secara memuaskan.

Kualitas pelayanan berpusat pada pemenuhan kebutuhan dan keinginan serta ketepatan penyampaian untuk mengimbangi harapan konsumen. Ada dua faktor yang mempengaruhi kualitas jasa yaitu expected service dan perceived service. Kualitas harus dimulai dari kebutuhan konsumen dan berakhir pada persepsi konsumen.

Beberapa penelitian terdahulu terkait dengan kualitas pelayanan commuter line telah dilakukan. Kualitas pelayanan commuter line dapat dipengaruhi oleh jadwal dan tarif kereta (Saidah, 2017), yang mengukur pengaruh jadwal dan tarif kereta terhadap kualitas pelayanan. Kualitas pelayanan adalah segala bentuk aktivitas yang dilakukan perusahaan jasa untuk memenuhi keinginan atau memuaskan konsumen dengan cara memberikan atau menyampaikan jasa yang melebihi harapan konsumen (Yunus dan Budianto, 2014), (Ardi, F.F, Mariam, I dan Widhi, 2016) menyatakan bahwa kualitas pelayanan berpengaruh terhadap kepuasan konsumen.

Selain kualitas pelayanan yang baik, faktor fasilitas juga merupakan faktor yang penting dalam menentukan kepuasan konsumen dan juga fasilitas merupakan suatu faktor yang menunjang dalam kegiatan usaha dalam memasarkan produk/jasa kepada konsumen. Fasilitas merupakan tolak ukur dari semua pelayanan yang diberikan serta sangat tinggi pengaruhnya terhadap kepuasan pelanggan. Karena dengan tingkat fasilitas yang ada juga sangat memudahkan pelanggan dalam beraktivitas serta nyaman untuk menggunakan fasilitas yang ada (Srijani, 2017). Semakin lengkapnya fasilitas yang disediakan oleh PT KCI di setiap stasiunnya maka semakin tingginya kepuasan konsumen terhadap PT KCI selaku penyedia jasa transportasi yaitu kereta api commuter line.

Sampai saat ini meskipun banyak diminati oleh masyarakat, transportasi kereta api commuter line dengan rute Cikarang - Jakarta Kota adalah rute baru sehingga dalam pengoperasiannya masih diwarnai oleh berbagai persoalan yang kompleks. Ketidakpuasan konsumen muncul karena hampir setiap hari transportasi kereta api commuter line mengalami keterlambatan dan jadwal harian kereta api commuter line yang terlalu sedikit. Waktu tunggu antar kedatangan kereta yang terlalu lama sekitar 25 menit sampai 85 menit untuk menunggu kedatangan kereta api commuter line. Hal ini mengakibatkan penumpukan penumpang pada stasiun Cikarang serta dapat menimbulkan ketidakpuasan penumpang kereta terhadap jasa commuter line.

Terdapat beberapa hal yang mengakibatkan ketidakpuasan konsumen terhadap pelayanan yang diberikan PT KCI diantaranya adalah: kurangnya loket pembelian tiket non reguler dan tidak ada pemisahan loket pembelian dan penukaran tiket mengakibatkan terjadi antrean yang panjang terutama di jam-jam sibuk, kurang tersedianya papan informasi mengakibatkan kebingungan sehingga calon penumpang harus bertanya kepada para petugas stasiun atau calon penumpang yang lainnya, kurangnya petugas keamanan di stasiun serta di dalam gerbong untuk menindak para penumpang yang tidak disiplin terhadap peraturan-peraturan, kurangnya 
keamanan di tempat parkir kendaraan, serta yang paling krusial adalah kurangnya jumlah gerbong yang tersedia yang tidak sebanding dengan jumlah penumpang.

PT KCI memahami bahwa peningkatan kualitas pelayanan dan berbagai fasilitas penunjang transportasi kereta api commuter line harus terus ditingkatkan agar para konsumen merasa nyaman dan aman dalam menggunakan moda transportasi tersebut. Diharapkan apabila pelayanan dan fasilitas yang diberikan sudah maksimal maka para konsumen dapat merasa puas. Untuk tercapainya kepuasan konsumen dibutuhkan inovasi - inovasi baru dan komitmen yang kuat dari PT KCI.

\section{RUANG LINGKUP}

Dalam penelitian ini penulis membatasi permasalahan yang terkait dengan fasilitas dan kualitas pelayanan kereta api commuter line khususnya untuk Jurusan Cikarang - Jakarta Kota yang meliputi rute Cikarang - Cibitung - Tambun sampai Bekasi Timur. Rute ini merupakan salah satu rute yang selalu dipadati konsumen setiap waktu. Tidak hanya di waktu tertentu seperti jam sibuk namun hampir keseluruhan jadwal selalu dipadati oleh konsumen.

Untuk itu penulis sangat tertarik untuk melakukan penelitian mengenai fasilitas dan kualitas pelayanan commuter line jurusan Cikarang - Jakarta Kota ini dengan mengukur:

1. Seberapa besar pengaruh fasilitas terhadap kepuasan konsumen Kereta Api Commuter Line dengan rute Cikarang - Jakarta Kota?

2. Seberapa besar pengaruh kualitas pelayanan terhadap kepuasan konsumen Kereta Api Commuter Line dengan rute Cikarang - Jakarta Kota?

3. Seberapa besar pengaruh fasilitas dan kualitas pelayanan secara simultan terhadap kepuasan konsumen Kereta Api Commuter Line dengan rute Cikarang - Jakarta Kota?

Dari hasil penelitian ini pada akhirnya akan diperoleh berbagai informasi yang berkaitan dengan kondisi fasilitas, kualitas pelayanan dan kepuasan konsumen PT KCI khususnya bagi para pengguna commuter line jurusan Jakarta Kota - Cikarang. Informasi tersebut tentunya akan sangat berguna bagi berbagai pihak yang berkepentingan terutama adalah bagi pihak pengelola yaitu PT KCI. Dengan tingkat kepuasan konsumen yang maksimal diharapkan timbul loyalitas dari konsumen untuk dapat terus menggunakan moda transportasi commuter line ini menjadi satu satunya moda transportasi andalan. Hal ini secara tidak langsung akan berpengaruh terhadap kinerja PT KCI. Peningkatan kinerja perusahaan akan diikuti dengan meningkatnya nilai perusahaan dimata para stakeholders.

\section{BAHAN DAN METODE}

Berikut ini disajikan kajian teoretis dan tahapantahapan penelitian ini.

\subsection{Kualitas Pelayanan}

Secara umum pengertian kualitas Pelayanan adalah segala bentuk aktivitas yang dilakukan perusahaan guna memenuhi harapan konsumen. Kualitas pelayanan dapat didefinisikan sebagai seberapa jauh perbedaan antara kenyataan dan harapan pelanggan atas kepuasan pelanggan yang mereka terima atau peroleh (Krisdayanto I., Haryono, A.I. dan Gagah, 2018). Menurut Tjiptono dalam (Rahmawati, A., Arifin, R., dan Hufron, 2019) Kualitas Pelayanan pada dasarnya prinsip kualitas jasa (kualitas pelayanan) berinti pada upaya pemenuhan kepuasan dan keinginan konsumen dan keakuratan penyampaian dalam mengimbangi harapan konsumen. Jika kualitas pelayanan semakin baik, dilakukan pada pelayanan yang handal, mempunyai daya tanggap, mempunyai jaminan pelayanan dan empati (rasa perhatian) yang baik, maka pelanggan akan merasa puas

Dari berbagai uraian di atas dapat disimpulkan bahwa kualitas pelayanan adalah segala bentuk aktivitas yang dilakukan perusahaan jasa untuk memenuhi keinginan atau memuaskan konsumen dengan cara memberikan atau menyampaikan jasa yang melebihi harapan konsumen.

Kualitas pelayanan memiliki tiga bentuk fungsi dasar pelayanan, ketiga fungsi ini adalah pelayanan dengan lisan, pelayanan dengan tulisan, dan pelayanan dengan perbuatan. Adapun faktor - faktor dominan yang dapat mempengaruhi kualitas pelayanan publik adalah sebagai berikut:

1. Motivasi kerja birokrasi dan aparatur

2. Kemampuan aparatur

3. Pengawasan/kontrol sosial

4. Perilaku birokrasi/aparatur

5. Komunikasi, disposisi dan struktur birokrasi serta iklim komunikasi organisasi dan aliran informasi

6. Restrukturisasi organisasi

Menurut (Tjiptono, 2014) untuk mengevaluasi kualitas jasa pelanggan umumnya menggunakan 5 dimensi adalah sebagai berikut :

1. Tangibles merupakan bukti nyata dari kepedulian dan perhatian yang diberikan oleh penyedia jasa kepada konsumen. Pentingnya dimensi tangibles ini akan menimbulkan image penyedia jasa terutama pada konsumen baru dalam mengevaluasi kualitas jasa.

2. Reliability atau keandalan merupakan kemampuan perusahaan untuk melaksanakan jasa sesuai dengan apa yang telah dijanjikan secara tepat waktu. Pentingnya dimensi ini adalah kepuasan pelanggan akan menurun bila jasa yang diberikan tidak sesuai dengan yang dijanjikan.

3. Responsiveness atau daya tangkap merupakan kemampuan perusahaan yang dilakukan langsung oleh karyawan untuk memberikan pelayanan dengan cepat dan tanggap.

4. Assurance atau jaminan merupakan pengetahuan dan perilaku karyawan untuk membangun kepercayaan 
dan keyakinan pada diri pelanggan dalam mengonsumsi jasa yang ditawarkan.

5. Empati merupakan kemampuan perusahaan yang dilakukan langsung oleh karyawan untuk memberikan perhatian kepada pelanggan secara individu, termasuk juga kepekaan akan kebutuhan pelanggan.

\subsection{Fasilitas}

Secara umum pengertian fasilitas adalah segala sesuatu yang dapat memudahkan konsumen dalam memperoleh kepuasan. Menurut (Tjiptono, 2014) mengatakan fasilitas adalah sumber daya fisik yang harus ada sebelum suatu jasa dapat ditawarkan kepada konsumen. Fasilitas dapat pula berupa segala sesuatu yang memudahkan konsumen dalam memperoleh kepuasan. Menurut Kottler dalam (Sofyan I.L, 2013) fasilitas merupakan segala sesuatu yang bersifat fisik yang disediakan oleh pihak penjual jasa untuk mendukung kenyamanan konsumen. Dari berbagai uraian tersebut dapat disimpulkan bahwa fasilitas adalah sarana prasarana pendukung yang bersifat fisik yang disediakan oleh perusahaan penjual jasa untuk mendukung kenyamanan konsumen.

Menurut (Krisdayanto I., Haryono, A.I. dan Gagah, 2018) beberapa faktor yang perlu diperhatikan dalam merancang dukungan fisik atau fasilitas fisik, diantaranya adalah:

1. Desain fasilitas

2. Nilai fungsi

3. Estetika

4. Kondisi yang mendukung

5. Peralatan penunjang

6. Seragam pegawai

7. Laporan - laporan

8. Garansi

\subsection{Kepuasan Konsumen}

Secara umum pengertian kepuasan konsumen adalah penilaian konsumen terhadap produk atau pelayanan yang telah memberikan tingkat kenikmatan seperti yang diharapkan. Seorang konsumen, jika merasa puas dengan nilai yang diberikan oleh produk atau jasa, sangat besar kemungkinannya menjadi pelanggan dalam waktu yang lama. Menurut (Krisdayanto I., Haryono, A.I. dan Gagah, 2018) kepuasan pelanggan adalah perasaan senang atau kecewa seseorang sebagai hasil dari perbandingan antara prestasi atau jasa yang dirasakan dan yang diharapkannya.

Dari berbagai uraian tersebut dapat disimpulkan bahwa kepuasan konsumen adalah penilaian konsumen terhadap produk atau pelayanan setelah membandingkan kinerja dimana kepuasan dan ketidakpuasan ditentukan oleh harapan dan persepsi konsumen.

Untuk mengukur kepuasan pelanggan ada empat cara yaitu sebagai berikut menurut Kotler dan Keller (Tjiptono, 2014) :
1. Ghost atau mystery shopping

Ghost atau mystery dapat dilakukan dengan memperkerjakan beberapa orang (ghost shoppers) dengan peran sebagai pesaing dan pelanggan potensial perusahaan. Adapun hal tersebut dilakukan untuk memperoleh informasi tentang kelemahan dan kekuatan perusahaan tersebut dan perusahaan pesaing. Selain itu tugas ghost shoppers adalah untuk mengetahui secara langsung mengenai bagaimana kinerja karyawan.

2. Analisis Lost Customer

Perusahaan sebaiknya mencoba untuk selalu menanyakan dan menghubungi pelanggan khususnya yang telah berhenti menggunakan dan membeli jasa atau produk dan berubah menjadi pesaing, sehingga perusahaan dapat mengetahui permasalahan dan dapat segera memperbaikinya.

3. Survei kepuasan pelanggan

Hampir sebagian besar perusahaan melakukan riset/penelitian melalui survei untuk mengetahui dan mengukur seberapa besar kepuasan pelanggan. Dengan metode ini, perusahaan dapat memperoleh umpan balik dan tanggapan dari pelanggan.

4. Sistem saran dan keluhan

Setiap perusahaan yang berpusat pada pelanggan sebaiknya selalu memberi kesempatan dan peluang kepada pelanggannya untuk menyampaikan keluhan, saran dan kritik kepada perusahaan. Hal tersebut dapat dilakukan melalui berbagai media seperti kartu komentar kotak saran, dan telepon layanan konsumen,. Informasi tersebut, perusahaan dapat dengan cepat memperbaiki berbagai masalah yang ada sehingga tidak akan lagi mengganggu kenyamanan pelanggan dalam penggunaan jasa atau produk perusahaan.

\subsection{Pendekatan dan Jenis Penelitian}

Penelitian dilaksanakan di Stasiun Cikarang dengan pertimbangan bahwa Stasiun Cikarang merupakan stasiun dengan jumlah konsumen cukup padat setiap waktu keberangkatan kereta. Metode penelitian yang digunakan dalam penelitian ini yaitu penelitian survei yang merupakan salah satu bagian dari pendekatan penelitian kuantitatif. Penelitian ini termasuk penelitian kuantitatif karena tujuan akhir dari penelitian ini adalah menguji dan menunjukkan pengaruh antar variabel menggunakan teknik analisis data statistik. Instrumen yang digunakan pada penelitian ini adalah kuesioner yang dibagikan kepada 100 orang responden. Terdiri dari laki-laki sebanyak 47 orang dan wanita sebanyak 53 orang. Dengan tingkat pendidikan mulai dari SD sampai dengan S2. Teknik pengambilan sampel pada penelitian ini yaitu sampling purposive. Pertimbangan yang digunakan saat pengambilan sampel pada penelitian ini yaitu responden yang akan dijadikan sampel merupakan responden yang sudah pernah menggunakan layanan Commuter Line dengan intensitas yang cukup banyak setiap minggunya. 
Dalam teknik analisa data statistik, aplikasi yang digunakan adalah aplikasi SPSS. SPSS adalah sebuah program aplikasi yang memiliki kemampuan analisis statistik cukup tinggi serta sistem manajemen data pada lingkungan grafis dengan menggunakan menu-menu deskriptif dan kotak-kotak dialog yang sederhana sehingga mudah untuk dipahami.

\subsection{Teknik Sampling}

Menurut (Sugiyono, 2017) mengatakan: Populasi adalah wilayah generalisasi yang terdiri atas: obyek/subyek yang mempunyai kualitas dan karakteristik tertentu yang ditetapkan oleh peneliti untuk diteliti dan kemudian ditarik kesimpulannya.

Dalam penelitian ini, yang akan diteliti adalah konsumen Kereta Api Commuter Line rute Cikarang Jakarta Kota dan lebih dikhususkan di stasiun Cikarang, Cibitung, Tambun, dan Bekasi Timur. Menurut (Sugiyono, 2017) sampel adalah bagian dari Jumlah dan karakteristik yang dimiliki oleh populasi.

Teknik pengambilan sampel pada penelitian ini adalah nonprobability sampling dan sampling insidental. Menurut (Sugiyono, 2017) Nonprobability Sampling adalah teknik pengambilan sampel yang tidak memberikan peluang/kesempatan sama bagi setiap unsur atau anggota populasi untuk dipilih menjadi sampel. Teknik sampel ini meliputi, sampling sistematis, kuota, aksidental, purposive, jenuh, snowball.

Dikarenakan populasinya yang tak terbatas atau infinity untuk menentukan jumlah sampel yang akan diteliti memerlukan rumus sampel infinity, untuk mengetahui berapa jumlah sampel yang akan diambil, adapun rumus infinity sampel besar menurut (Sumarni, Murti dan Salamah, 2016) disajikan dalam (1).

$$
\mathrm{n}=\frac{\mathrm{Z}^{2}}{4(\text { Moe })^{2}}
$$

Keterangan :

$$
\begin{array}{ll}
\mathrm{n} & =\text { Jumlah sampel } \\
\mathrm{Z}^{2} & =\text { Tingkat distribusi normal pada taraf }
\end{array}
$$$$
\text { signifikansi } 5 \%=1,96
$$

$(\text { Moe })^{2}=$ Margin of Error, merupakan besarnya tingkat kesalahan maksimal sampel yang diambil dan yang masih dapat diinginkan atau yang ditoleransi.

Sehingga dengan demikian Margin of Error sebesar $10 \%$, maka hasil jumlah sampel yang dapat diambil sebesar (2)

$$
\begin{aligned}
& \mathrm{n}=\frac{1,96^{2}}{4(0.10)^{2}} \\
& \mathrm{n}=96,04
\end{aligned}
$$

Dengan demikian, berdasarkan perhitungan ukuran sampel infinity (2), jumlah responden yang akan dijadikan sampel dalam penelitian ini adalah sekitar 96,04 responden atau dibulatkan menjadi 100 responden.

\subsection{Teknik Analisis Data}

Berikut langkah - langkah dalam menganalisis data penelitian kuantitatif adalah sebagai berikut:

\subsubsection{Validity Test}

Validity test atau uji validitas merupakan suatu tahapan langkah atau prosedur untuk mengetahui apakah pertanyaan-pertanyaan atau questioner yang akan diajukan kepada responden dan dipakai untuk mengukur variabel penelitian valid atau tidak. Pertanyaanpertanyaan dikatakan valid bila dapat menginformasikan atau mengukur apa yang menunjukkan kevalidan dari instrumen-instrumen yang ditetapkan. Rumus statistik yang digunakan adalah Statistik Koefisien Korelasi product moment dalam (Siregar, 2012) sebagaimana disajikan dalam (3).

$\mathrm{r}_{\mathrm{xy}}=\frac{n\left(\sum X Y\right)-\left(\sum X\right) \cdot\left(\sum Y\right)}{\sqrt{\left[n \cdot \sum X^{2}-\left(\sum X\right)^{2}\right] \cdot\left\{n \cdot \sum Y^{2}-\left(\sum Y\right)^{2}\right\}}}$

Keterangan (3)

$\mathrm{r}_{\mathrm{xy}} \quad$ : Koefisien Korelasi

$\sum X \quad$ : Hasil jumlah skor butir

$\sum Y \quad$ : Hasil jumlah total skor butir

$\sum X^{2} \quad$ : Hasil jumlah kuadran skor butir

$\sum Y^{2} \quad$ : Hasil jumlah kuadranSDRT L total skor butir

$\sum X Y$ : Hasil penjumlahan perkalian skor butir dengan total skor butir

$n \quad$ : Banyak sampel uji coba (responden)

Karena dengan angka kasar relatif lebih mudah dan akan dapat menghindari angka pecahan. Sedangkan mengenai perhitungan korelasinya berdasarkan ketentuan bahwa jika $r_{x y}>r_{\text {tabel }}$ signifikansi $5 \%$ berarti item (butir soal) dinyatakan valid. Sebaliknya jika $r_{x y}<r_{\text {tabel }}$ maka butir soal tidak valid sekaligus tidak memiliki persyaratan.

\subsubsection{Reability Test}

Reliabilitas terkait mengenai ketepatan di dalam alat ukur yang dapat dinilai melalui analisa statistik guna menghitung kesalahan ukuran. Suatu instrumen yang telah ditetapkan dianggap reliabel bila instrumen tersebut dapat dipercaya sebagai alat ukur data peneliti. Menurut (Siregar, 2012) mengatakan reliabilitas adalah untuk mengetahui sejauh mana hasil pengukuran tetap konsisten apabila dilakukan pengukuran dua kali atau lebih terhadap gejala yang sama dengan menggunakan alat pengukur yang sama pula.

Pengukuran reliabilitas yaitu menggunakan teknik Alpha Cronbach disajikan dalam (4).

$\mathrm{r}_{11}=\left(\frac{k}{k-1}\right)\left(1-\frac{\sum \sigma_{b}^{2}}{\sigma_{t}^{2}}\right)$

Keterangan :

$$
\begin{array}{ll}
\mathrm{r}_{11} & =\text { koefisien reliabilitas instrumen } \\
\mathrm{k} & =\text { jumlah butir pertanyaan } \\
\sum \sigma_{b}^{2} & =\text { jumlah varians butir } \\
\sigma_{t .}^{2} & =\text { varians total }
\end{array}
$$

Kriteria instrumen penelitian dikatakan reliabel dengan menggunakan teknik ini bila koefisien reliabilitas $\left(r_{11}\right)>0,60$ (Siregar, 2012). Pengujian reliabilitas dalam penelitian ini menggunakan program SPSS. 


\subsubsection{Analisis Regresi Linear Berganda}

Analisis regresi linear berganda merupakan hubungan antara dua atau lebih variabel independen $\left(\mathrm{X}_{1}\right.$, $\left.\mathrm{X}_{2}, \ldots . \mathrm{X}_{\mathrm{n}}\right)$ dengan variabel dependen $(\mathrm{Y})$ secara linear. Penggunaan analisa ini untuk mengetahui seberapa besar hubungan antara variabel dependen dengan variabel independen apakah masing-masing variabel independen hubungan positif atau negatif dan untuk memprediksi nilai dari dependen apabila nilai variabel independen mengalami penurunan atau kenaikan. Untuk data yang sering digunakan biasanya skala rasio atau interval. Analisis regresi berganda dapat disajikan (5).

$$
\mathrm{Y}=\mathrm{a}+\mathrm{b}_{1} \mathrm{x}_{1}+\mathrm{b}_{2} \mathrm{x}_{2}
$$

\section{Dimana:}

Y = besarnya Kepuasan Konsumen

a $\quad=$ Bilangan konstanta

$\mathrm{b}_{1} \mathrm{~s} / \mathrm{d} \mathrm{b}_{2}=$ Koefisien regresi yang akan dihitung

$\mathrm{X}_{1} \quad=$ besarnya Kualitas Pelayanan

$\mathrm{X}_{2} \quad=$ besarnya Fasilitas

\subsubsection{Analisis Koefisien Determinasi}

Koefisien determinasi bertujuan untuk mengetahui seberapa besar kemampuan variabel independen menjelaskan variabel dependen. Dalam output SPSS, koefisien determinasi terletak pada tabel Model Summary dan tertulis Adjusted $R$ Square. Nilai $\mathrm{R}^{2}$ sebesar 1, berarti pengaruh variabel dependen seluruhnya dapat dijelaskan oleh variabel independen dan tidak ada faktor lain yang menyebabkan pengaruh variabel dependen. Jika nilai Adjusted $\mathrm{R}^{2}$ berkisar antara 0 sampai dengan 1, berarti semakin kuat kemampuan variabel independen dapat menjelaskan pengaruh variabel dependen (Ghozali, 2016) Adapun rumus koefisien determinasi (KD) disajikan (6).

$$
\mathrm{Kd}=\mathrm{r}^{2} \times 100 \%
$$

Keterangan (6)

$$
\begin{aligned}
& \mathrm{Kd}=\text { Koefisien Determinasi } \\
& \mathrm{r}^{2}=\text { Koefisien Korelasi }
\end{aligned}
$$

\subsubsection{Uji Hipotesis}

Terdapat 2 jenis pengujian dalam pengujian hipotesis dijabarkan sebagai berikut:

\section{Uji Parsial (Uji T)}

Uji $\mathrm{T}$ ini biasanya digunakan untuk mengetahui seberapa besar signifikansi pengaruh variabel independen terhadap variabel dependen secara individual dan menganggap variabel dependen yang lain konstan (Ghozali, 2016). Pengaruh yang signifikan dapat di estimasi dengan membandingkan antara nilai $\mathrm{T}_{\text {tabel }}$ dengan nilai $\mathrm{T}_{\text {hitung }}$.

Apabila nilai $\mathrm{T}_{\text {hitung }}>\mathrm{T}_{\text {tabel }}$ maka variabel independen secara individual mempengaruhi variabel dependen, sebaliknya jika nilai $\mathrm{T}_{\text {hitung }}<\mathrm{T}_{\text {tabel }}$ maka variabel independen secara individual tidak mempengaruhi variabel dependen. $T_{\text {hitung }}>T_{\text {tabel }}$ berarti $\mathrm{H} 1$ diterima dan $\mathrm{H} 0$ di tolak $\mathrm{T}_{\text {hitung }}<\mathrm{T}_{\text {tabel }}$ berarti $\mathrm{H} 1$ ditolak dan $\mathrm{H} 1$ diterima. Uji parsial atau uji $\mathrm{T}$ ini juga dapat dilihat pada tingkat signifikansinya:

1) Jika tingkat signifikansi $<0,05$, maka $\mathrm{H} 0$ ditolak dan $\mathrm{H} 1$ diterima

2) Jika tingkat signifikansi $>0,05$, maka $\mathrm{H} 0$ diterima dan $\mathrm{H} 1$ ditolak

2. Uji Simultan (Uji F)

Pengujian ini bertujuan untuk membuktikan apakah variabel-variabel independen (X) secara simultan (bersama-sama) mempunyai pengaruh terhadap variabel dependen (Y) (Ghozali, 2016).

Uji simultan (uji F) ini digunakan untuk mengetahui pengaruh secara bersama-sama independen variabel bebas terhadap dependen variabel terikat. Dimana $\mathrm{F}_{\text {hitung }}>\mathrm{F}_{\text {tabel }}$, maka $\mathrm{H} 1$ diterima atau secara bersamasama variabel bebas dapat menerangkan variabel terikatnya secara serentak. Sebaliknya apabila $\mathrm{F}_{\text {hitung }}<\mathrm{F}_{\text {tabel }}$, maka $\mathrm{H} 0$ diterima atau secara bersamasama variabel bebas tidak memiliki pengaruh terhadap variabel terikat. Untuk mengetahui signifikan atau tidak pengaruh secara bersama-sama variabel bebas terhadap variabel terikat maka digunakan probability sebesar 5\% $(\alpha=0,05)$.

Jika sig > $\alpha(0,05)$, maka H0 diterima H1 ditolak.

Jika sig < $\alpha(0,05)$, maka H0 ditolak H1 diterima.

\section{PEMBAHASAN}

Di bawah ini disampaikan hasil dan pembahasan pengukuran variabel dengan menggunakan software pengolahan data SPSS.

\subsection{Korelasi product moment}

Untuk mengetahui seberapa kuat pengaruh kualitas pelayanan dan fasilitas terhadap kepuasan konsumen

\begin{tabular}{|c|c|c|c|c|}
\hline \multicolumn{5}{|c|}{ Correlations } \\
\hline & & $\begin{array}{l}\text { Kualitas } \\
\text { Pelayanan }\end{array}$ & Fasilitas & $\begin{array}{l}\text { Kepuasan } \\
\text { konsumen }\end{array}$ \\
\hline \multirow[t]{3}{*}{$\begin{array}{c}\text { Kualitas } \\
\text { Pelayanan }\end{array}$} & $\begin{array}{c}\text { Pearson } \\
\text { Correlation }\end{array}$ & 1 & ,949** &, $941^{\text {*** }}$ \\
\hline & $\begin{array}{c}\text { Sig. } \\
\text { (2-tailed) }\end{array}$ & & ,000 & ,000 \\
\hline & $\mathrm{N}$ & 100 & 100 & 100 \\
\hline \multirow[t]{3}{*}{ Fasilitas } & $\begin{array}{c}\text { Pearson } \\
\text { Correlation }\end{array}$ & ,949** & 1 &, $976^{* * *}$ \\
\hline & $\begin{array}{c}\text { Sig. } \\
\text { (2-tailed) }\end{array}$ & ,000 & & ,000 \\
\hline & $\mathrm{N}$ & 100 & 100 & 100 \\
\hline \multirow[t]{3}{*}{$\begin{array}{l}\text { Kepuasan } \\
\text { konsumen }\end{array}$} & $\begin{array}{c}\text { Pearson } \\
\text { Correlation }\end{array}$ & ,941** & $976^{* *}$ & 1 \\
\hline & $\begin{array}{c}\text { Sig. } \\
\text { (2-tailed) }\end{array}$ & ,000 & ,000 & \\
\hline & $\mathrm{N}$ & 100 & 100 & 100 \\
\hline
\end{tabular}
maka diperlukan uji korelasi produk momen. Adapun tabel uji korelasi produk momen dalam tabel 1.

Tabel 1. Uji korelasi produk moment 
Berdasarkan tabel 1 dapat disimpulkan dengan merujuk berdasarkan nilai signifikan dari tiap variabel di atas diketahui antara kualitas pelayanan dengan fasilitas didapatkan nilai signifikansi $0,000<0,050$ yang berarti adanya korelasi yang cukup signifikan antara kualitas pelayanan dan fasilitas. Kemudian, antara kualitas pelayanan dengan kepuasan konsumen didapatkan nilai signifikansi $0,000<0,050$ menginformasikan bahwa terdapat korelasi yang signifikan antara kualitas pelayanan dengan kepuasan konsumen. Sedangkan, antara fasilitas dengan kepuasan konsumen didapatkan nilai signifikansi $0,000<0,050$ menginformasikan bahwa ada korelasi yang signifikan antara fasilitas dengan kepuasan konsumen.

\subsection{Analisis Regresi Linear Berganda}

Dalam penelitian ini analisis regresi berganda berperan untuk mengetahui dan menginformasikan hubungan antara variabel bebas/independen dengan variabel terikat/dependen apakah setiap variabel independen hubungan positif atau negatif dan untuk memperkirakan nilai dari dependen apabila nilai variabel independen adakah kenaikannya atau penurunannya. Adapun tabel uji regresi berganda disajikan dalam tabel 2.

Tabel 2. Uji Regresi Linear Berganda.

\begin{tabular}{|c|c|c|c|c|c|}
\hline \multicolumn{7}{|c|}{ Coefficients $^{\mathrm{a}}$} \\
\hline Model & \multicolumn{2}{|c|}{$\begin{array}{c}\text { Unstandardized } \\
\text { Coefficients }\end{array}$} & $\begin{array}{c}\text { Standardized } \\
\text { Coefficients }\end{array}$ & \multirow{2}{*}{ Sig. } & \\
\cline { 2 - 4 } & $\mathrm{B}$ & $\begin{array}{c}\text { Std. } \\
\text { Error }\end{array}$ & Beta & & \\
\hline (Constant) & 2,05 &, 764 & & 2,68 &, 009 \\
\hline $\begin{array}{c}\text { Kualitas } \\
\text { Pelayanan }\end{array}$ &, 084 &, 042 &, 137 & 1,99 &, 049 \\
\hline Fasilitas &, 636 &, 051 &, 847 & 12,3 &, 000 \\
\hline a. Dependent Variable: Kepuasan Konsumen \\
\hline
\end{tabular}

Berdasarkan tabel 2. diperoleh hasil persamaan regresi (7):

$$
\mathrm{Y}=2,051+0,084 \mathrm{x}_{1}+0,636 \mathrm{x}_{2}
$$

Kesimpulannya variabel kualitas pelayanan berpengaruh positif terhadap kepuasan konsumen sebesar 0,084 dengan tingkat signifikansi $0,049>0,050$. Yang berarti bahwa setiap terjadi kenaikan variabel kualitas pelayanan 1 satuan maka kepuasan konsumen akan naik sebesar 0,084. Sedangkan untuk variabel fasilitas berpengaruh positif dan signifikan terhadap kepuasan konsumen sebesar 0,636 dengan tingkat signifikansi $0,000>0,050$. Yang berarti bahwa setiap terjadi kenaikan variabel fasilitas 1 satuan maka kepuasan konsumen akan naik sebesar 0,636. Jadi kualitas pelayanan dan fasilitas masing-masing memiliki hubungan yang berpengaruh positif terhadap kepuasan konsumen namun pengaruh fasilitas lebih besar dari pada pengaruh kualitas pelayanan.

\subsection{Koefisien Determinasi}

Untuk mengetahui berapa besar kontribusi yang diberikan oleh kualitas pelayanan dan fasilitas terhadap kepuasan konsumen, maka digunakan uji koefisien determinasi. Adapun tabel uji koefisien determinasi adalah sebagai berikut:

\section{Kualitas Pelayanan}

Dari tabel 3. dapat disimpulkan bahwa variabel kualitas pelayanan terhadap kepuasan konsumen secara parsial berpengaruh positif dan signifikan dengan nilai Adjusted $R$ Square adalah sebesar 0,891 (nilai 0,891 adalah pengkuadratan dari koefisien korelasi atau R, yaitu $0,945 \times 0,945=0,891$ ) menunjukkan bahwa besar pengaruh kualitas pelayanan secara parsial sebesar $89,1 \%$

Tabel 3. Uji Koefisien Determinasi Kualitas Pelayanan

\begin{tabular}{|c|c|r|r|c|}
\hline \multicolumn{5}{|c|}{ Model Summary } \\
\hline Model & $\mathrm{R}$ & $\begin{array}{c}\mathrm{R} \\
\text { Square }\end{array}$ & $\begin{array}{c}\text { Adjusted } \\
\text { R Square }\end{array}$ & $\begin{array}{c}\text { Std. Error } \\
\text { of the } \\
\text { Estimate }\end{array}$ \\
\hline 1 &, $945^{\mathrm{a}}$ &, 892 &, 891 & 1,615 \\
\hline \multicolumn{4}{|l}{ a. Predictors: (Constant), Kulitas Pelayanan } \\
\hline
\end{tabular}

\section{Fasilitas}

Dari tabel 4. dapat disimpulkan bahwa variabel fasilitas terhadap kepuasan konumen secara parsial berpengaruh positif dan signifikan dengan nilai Adjusted $R$ Square adalah sebesar 0,952 (nilai 0,891 adalah pengkuadratan dari koefisien korelasi atau $\mathrm{R}$, yaitu $0,976 \times 0,976=0,952)$, menunjukkan bahwa besar pengaruh fasilitas secara parsial sebesar 95,2\%.

Tabel 4. Uji Koefisien Determinasi Fasilitas

\begin{tabular}{|c|c|c|c|c|}
\hline \multicolumn{5}{|c|}{ Model Summary } \\
\hline Model & $\mathrm{R}$ & R Square & $\begin{array}{l}\text { Adjusted R } \\
\text { Square }\end{array}$ & $\begin{array}{l}\text { Std. Error of } \\
\text { the Estimate }\end{array}$ \\
\hline 1 & ,977 & 955 & 954 & 1,045 \\
\hline
\end{tabular}

Pengujian uji koefisien determinasi secara simultan disajikan dalam tabel 5.

Tabel 5. Uji Koefisien Determinasi Secara Simultan

\begin{tabular}{|c|c|c|c|r|}
\hline \multicolumn{5}{|c|}{ Model Summary } \\
\hline Model & $\mathrm{R}$ & $\mathrm{R}$ Square & $\begin{array}{c}\text { Adjusted R } \\
\text { Square }\end{array}$ & $\begin{array}{c}\text { Std. Error of } \\
\text { the Estimate }\end{array}$ \\
\hline 1 &, $976^{\mathrm{a}}$ &, 952 &, 952 & 1,077 \\
\hline \multicolumn{5}{|c|}{ a. Predictors: (Constant), Fasilitas } \\
\hline
\end{tabular}

Dari tabel 5. dapat disimpulkan bahwa variabel kualitas pelayanan dan fasilitas secara bersama - sama mempengaruhi kepuasan konsumen dengan nilai Adjusted $R$ Square adalah sebesar 0,954 (nilai 0,954 adalah pengkuadratan dari koefisien korelasi atau $\mathrm{R}$, yaitu $0,977 \times 0,977=0,954)$ menunjukkan bahwa besar 
pengaruh kualitas pelayanan dan fasilitas secara simultan sebesar 95,4\%. Hal ini berarti kepuasan konsumen dipengaruhi oleh kualitas pelayanan dan fasilitas sebesar $95,4 \%$, itu berarti hanya $4,6 \%$ dipengaruhi oleh faktor faktor lainnya yang dalam penelitian ini tidak dianalisis.

\subsection{Uji Parsial (Uji T)}

Berdasarkan penelitian pada uji $\mathrm{T}$ dengan menggunakan software pengolahan data SPSS 22.0 dengan tujuan untuk mengukur besarnya pengaruh fasilitas terhadap kepuasan konsumen dan pengaruh kualitas pelayanan terhadap kepuasan konsumen diperoleh hasil tabel 6.

Tabel 6. Uji T

\begin{tabular}{|c|c|c|c|c|c|c|}
\hline \multicolumn{7}{|c|}{ Coefficients $^{\mathrm{a}}$} \\
\hline \multirow{2}{*}{\multicolumn{2}{|c|}{ Model }} & \multicolumn{2}{|c|}{$\begin{array}{l}\text { Unstandardized } \\
\text { Coefficients }\end{array}$} & $\begin{array}{l}\text { Standardized } \\
\text { Coefficients }\end{array}$ & \multirow[t]{2}{*}{$\mathrm{T}$} & \multirow[t]{2}{*}{ Sig. } \\
\hline & & $\mathrm{B}$ & Std.Error & Beta & & \\
\hline \multirow[t]{3}{*}{1} & (Constant) & 2,051 & ,764 & & 2,685 & 009 \\
\hline & Kualitas Pelayanan &, 084 & 042 & 137 & 1,998 & 049 \\
\hline & Fasilitas &, 636 &, 051 & 847 & 12,394 &, 000 \\
\hline
\end{tabular}

Berdasarkan hasil dari tabel 6. diperoleh hasil perhitungan dengan tingkat kesalahan 5\% dengan nilai $\mathrm{T}_{\text {hitung }}$ sebesar 1,998 sedangkan $\mathrm{T}_{\text {tabel }}$ sebesar 1,660. Dengan demikian $T_{\text {hitung }}>\mathrm{T}_{\text {tabel }}$ berarti $\mathrm{H} 0$ ditolak dan menerima H1. Sedangkan signifikansi untuk kualitas pelayanan adalah sebesar 0,049 $<0,050$, maka dapat disimpulkan bahwa hipotesis diterima, artinya variabel kualitas pelayanan berpengaruh signifikan terhadap kepuasan konsumen serta, semakin baik kualitas pelayanan yang diberikan maka semakin tinggi kepuasan konsumen terhadap PT Kereta Commuter Indonesia.

Berdasarkan hasil dari tabel 6 di atas juga diperoleh hasil perhitungan dengan tingkat kesalahan 5\% dengan nilai $\mathrm{T}_{\text {hitung }}$ sebesar 12,394 sedangkan $\mathrm{T}_{\text {tabel }}$ sebesar 1,660. Dengan demikian $T_{\text {hitung }}>T_{\text {tabel }}$ berarti $\mathrm{H} 0$ ditolak dan menerima H1. Sedangkan signifikansi untuk fasilitas adalah sebesar $0,000<0,050$, maka dapat disimpulkan bahwa hipotesis diterima, artinya variabel fasilitas berpengaruh signifikan terhadap kepuasan konsumen serat, semakin baik fasilitas yang diberikan maka semakin tinggi kepuasan konsumen terhadap PT Kereta Commuter Indonesia.

\subsection{Uji Simultan (Uji F)}

Berdasarkan hasil uji simultan (uji F) dengan menggunakan software SPSS 22.0 untuk mengetahui seberapa besar pengaruh kualitas pelayanan dan fasilitas secara bersama-sama terhadap kepuasan konsumen diperoleh hasil dalam tabel 7.

\begin{tabular}{|c|c|c|c|c|c|c|c|}
\hline \multicolumn{6}{|c|}{$\begin{array}{l}\text { Tabel 7. Uji F } \\
\text { ANOVA }^{\mathrm{a}}\end{array}$} & & \\
\hline Model & $\begin{array}{l}\text { Sum of } \\
\text { Squares }\end{array}$ & Df & $\begin{array}{l}\text { Mean } \\
\text { Square } \\
\end{array}$ & $\mathrm{F}$ & Sig. & & \\
\hline Residual & 1 & $\begin{array}{l}\text { Regres } \\
\text { sion }\end{array}$ & $\begin{array}{l}2264,51 \\
8\end{array}$ & 2 & $\begin{array}{l}1132,2 \\
59 \\
\end{array}$ & $\begin{array}{l}1037 \\
, 674 \\
\end{array}$ &, $000^{\mathrm{b}}$ \\
\hline Total & $\begin{array}{l}2370,36 \\
0\end{array}$ & 99 & & & & & \\
\hline
\end{tabular}

Berdasarkan hasil dari tabel 7 uji $\mathrm{F}$ didapatkan hasil perhitungan dengan tingkat kesalahan $5 \%$ dan derajat kebebasan $(\mathrm{n}-\mathrm{k})$ dan $(\mathrm{k}-1)$ dengan nilai $F_{\text {hitung }}$ sebesar 1037,6 sedangkan $F_{\text {tabel }}$ sebesar 3,087. Dengan demikian $F_{\text {hitung }}>F_{\text {tabel }}$ berarti $\mathrm{H} 0$ ditolak dan menerima $\mathrm{H} 1$. Dengan signifikansi $\mathrm{F}$ untuk kepuasan konsumen adalah sebesar $0,000<0,050$, maka dapat disimpulkan bahwa hipotesis diterima, artinya variabel kualitas pelayanan dan fasilitas yang di berikan PT Kereta Commuter Indonesia berpengaruh secara bersama - sama dan saling mendukung dalam mempengaruhi kepuasan konsumen.

\section{KESIMPULAN}

Variabel kualitas pelayanan dan fasilitas berpengaruh positif dan signifikan terhadap kepuasan konsumen PT Kereta Commuter Indonesia baik secara parsial maupun simultan hal ini ditandai dengan hasil perhitungan nilai $\mathrm{T}_{\text {hitung }}$ lebih besar dari $\mathrm{T}_{\text {tats }}$. Sehingga $\mathrm{H} 0$ ditolak dan menerima H1. Signifikansi untuk kualitas pelayanan adalah sebesar $0,049<0,050$, artinya variabel kualitas pelayanan berpengaruh signifikan terhadap kepuasan konsumen. Semakin baik kualitas pelayanan yang diberikan maka semakin tinggi kepuasan konsumen di dalam menggunakan armada transportasi kereta commuter line. Sedangkan untuk variabel fasilitas berdasarkan hasil perhitungan diperoleh $T_{\text {hitung }}$ lebih besar dari $T_{\text {tstes }}$ sebesar sehingga $\mathrm{HO}$ ditolak dan menerima H1. Signifikansi untuk fasilitas adalah sebesar $0,000<0,050$, artinya variabel fasilitas berpengaruh signifikan terhadap kepuasan konsumen. Hal ini mengindikasikan bahwa semakin baik fasilitas yang diberikan maka semakin tinggi kepuasan konsumen di dalam menggunakan fasilitas commuter line. Berdasarkan hasil dari tabel uji $\mathrm{F}$ didapatkan hasil perhitungan dengan nilai $\mathrm{F}_{\text {hitung }}$ lebih besar dari $\mathrm{F}_{\text {trtel }}$ berarti H0 ditolak dan menerima H1. Signifikansi F untuk kepuasan konsumen adalah sebesar $0,000<0,050$, hipotesis diterima. Sehingga dapat disimpulkan bahwa kualitas pelayanan dan fasilitas secara simultan 
berpengaruh secara signifikan terhadap kepuasan konsumen. Untuk itu diharapkan PT KCI dapat terus meningkatkan fasilitas dan kualitas pelayanan demi kepuasan para pelanggan yang menggunakan commuter line.

\section{SARAN}

Adapun saran yang dapat penulis sampaikan berdasarkan hasil penelitian adanya pengaruh yang signifikan antara kualitas pelayanan dan fasilitas terhadap kepuasan konsumen kereta api commuter line dengan rute Cikarang - Jakarta Kota maka perlu disampaikan, dalam hal kualitas pelayanan PT Kereta Commuter Indonesia hendaknya lebih meningkatkan pelayanan terhadap konsumen terutama dalam memahami kebutuhan konsumennya seperti menambah loket untuk pembelian tiket. Dalam hal fasilitas PT Kereta Commuter Indonesia hendaknya menambah fasilitas armada kereta hal ini untuk menghindari penumpukan penumpang terutama pada jam sibuk. Selain penambahan armada yang perlu dilakukan oleh PT KCI untuk meningkatkan kepuasan pelanggan adalah dengan menambah jadwal keberangkatan kereta sehingga waktu menunggu konsumen dari satu kereta ke kereta berikutnya tidak terlalu lama. Untuk penelitian selanjutnya terkait dengan penggunaan kereta api commuter line, peneliti dapat menggunakan variabel lain yang belum pernah diteliti seperti loyalitas pelanggan, customer value dan harga. Harapannya setiap hasil penelitian dapat memberikan kontribusi dan masukkan bagi peningkatan kinerja PT KCI.

\section{DAFTAR PUSTAKA}

Ardi, F.F, Mariam, I., dan Widhi, N. 2016. Pengaruh Kualitas Pelayanan Pada Fasilitas Dan Petugas Cimmuter Line Ticket Vending Mechine (CVIM)Terhadap Kepuasaan Konsumen PT KAI Commuter Jabodetabek di Pondok Cina. Epigram, 13 No. 2(UNJ), 95-102.

Ghozali, I. 2016. Aplikasi Analisis Multivariate Dengan Program SPSS. Semarang: Badan Penerbit Universitas Diponegoro.

Hardiansyah. 2011. Kualitas Pelayanan Publik: Konsep, Dimensi, Indikator dan Implementasinya. Yogjakarta: Gava Media.

Krisdayanto I., Haryono, A.I., dan Gagah, E. 2018. Analisis Pengaruh Harga, Kualitas Pelayanan, Fasilitas, Dan Lokasi Terhadap Kepuasan Konsumen Di I Cafe Lina Putra Net BandungaN. Journal of Management, 4 No. 4(Universitas Pandanaran). Retrieved from https://jurnal.unpand.ac.id/index.php/MS/issue/vie w/47

Lovelock, C. dan W. J. 2011. Pemasaran Jasa Perspektif. Jakarta: Erlangga.

Rahmawati, A., Arifin, R. dan Hufron, M. 2019. Pengaruh kualitas pelayanan, harga, dan fasilitas terhadap kepuasan konsumen pada kapal penumpang km. Napoleon rute perjalanan kendariwanci (studi kasus PT Aksar saputra lines). EJurnal Riset Manajemen, 8 No.2(Unisma), 1-13. Retrieved from http://riset.unisma.ac.id/index.php/jrm/article/view/ 2196/2077

Saidah, D. 2017. Kualitas Pelayanan Commuter Line. Manajemen Transportasi Dan Logistik, 4 No.1(Sekolah Tinggi Manajemen Transportasi Trisakti), 51-57. Retrieved from https://www.researchgate.net/publication/3187043 09_kualitas_pelayanan_commuter_line_service_qu ality_of_commuter_line

Siregar, S. 2012. Metode Penelitian Kuantitatif Dilengkapi Dengan Perbandingan Perhitungan Manual dan SPSS. Jakarta: Prenadamedia Group.

Sofyan I.L, P. A. dan N. A. 2013. Pengaruh Fasilitas dan Kualitas Pelayanan Terhadap Loyalitas, Melalui Kepuasan Konsumen Sebagai Variabel Intervening pada Star Clean Car Wash Semarang. DIiponegoro Journal Of Social And Politic, (Undip), 1-12. Retrieved from http:ejournals1.undip.ac.id/index.php/

Srijani, N. dan H. A. 2017. Pegaruh Fasilitas Terhadap Kepuasan Pelanggan di Aston Madiun Hotel \& Conference Center. WIGA, 7(STIE Widya Gama Lumajang), 31-38. Retrieved from https://doi.org/10.30741/wiga.v7i1.336

Sugiyono. 2017. Metode Penelitian Kuantitatif, Kualitatif dan Kombinasi (MIXED METHODS). Bandung: Alfabeta.

Sumarni, Murti dan Salamah, W. 2016. Metode Penelitian Bisnis. Yogjakarta: Andi, Yogjakarta.

Tjiptono, F. 2014. Strategi Pemasaran (Kedua). Andi, Yogjakarta.

Yunus dan Budianto. 2014. Pengaruh Kualitas Pelayanan Dan Fasilitas Terhadap Kepuasan Pelanggan. Ilmu Dan Riset Manajemen, 3 No. 12(E-Journal Stiesa Surabaya).

\section{UCAPAN TERIMA KASIH}

Judul Dibiayai oleh Direktorat Riset dan Pengabdian Masyarakat Direktorat Jenderal Penguatan Riset dan Pengembangan Kementerian Riset dan Teknologi /

Badan Riset dan Inovasi Nasional Republik Indonesia sesuai Dengan Kontrak Penelitian Tahun Anggaran 2020. 